\title{
DIVERSIFIKASI DAN PENGOLAHAN PRODUK OLAHAN BERBASIS AIR KELAPA
}

\author{
Hermiza Mardesci, S.TP., MP \\ Program Studi Teknologi Pangan Universitas Islam Indragiri. Jalan Lintas Provinsi \\ Parit 1, Tembilahan, Indragiri Hilir \\ mimzaaci@yahoo.co.id
}

\begin{abstract}
Abstrak
Tulisan ini merangkum beberapa penelitian terkait diversifikasi dan pengolahan produk olahan berbasis air kelapa. Air kelapa merupakan bagian dari air kelapa yang bisa dimanfaatkan dan diolah lebih lanjut. Pengolahan dan penganekaragaman produk olahan tersebut akan meningkakan nilai tambah produk. Produk olahan yang bisa dihasilkan dari air kelapa adalah nata de coco, kecap, permen, sirup, permen, minuman isotonik, cuka, cocojell, dan lain sebagainya. Diversifikasi produk ini jika dilakukan di sentra-sentra kelapa di Indonesia, khususnya Kabupaten Indragiri Hilir, Riau akan dapat meningkatkan pendapatan petani kelapa secara finansial.
\end{abstract}

Kata Kunci : Air kelapa, nata de coco, sirup, kecap, permen, isotonik, diversifikasi.

\section{PENDAHULUAN}

Kelapa merupakan tanaman serbaguna, karena hampir semua bagian dari pohon kelapa dapat dimanfaatkan. Selain daging buah, air kelapa merupakan salah satu bagian dari kelapa yang dapat dikonsumsi. Air kelapa muda dapat dikonsumsi secara langsung sebagai minuman dingin yang menyegarkan. Air kelapa tua juga bisa dikonsumi dengan mengolahnya terlebih dahulu. Pengolahan dan diversifikasi produk yang dilakukan pada air kelapa, baik air kelapa muda maupun kelapa tua dapat meningkatkan nilai tambah. Beberapa penelitian terkait pengolahan air kelapa sudah banyak dilakukan. Tulisan ini akan merangkum beberapa penelitian yang telah membahas tentang pengolahan dan diversifikasi produk olahan berbasis air kelapa.

\section{DIVERSIFIKASI DAN PENGOLAHAN PRODUK DARI AIR KELAPA}

Diversifikasi merupakan penganekaragaman produk dalam usaha memenuhi kebutuhan konsumen. Usaha ini dilakukan untuk menghasilkan nilai tambah serta meningkatkan penjualan (Marsigit, 2010; Fitriani et al., 2011; Hermawan, 2015). Beragamnya produk yang dihasilkan dari satu sumber bahan baku akan meningkatkan jumlah konsumen, karena konsumen akan bebas memilih produk yang mereka sukai. Selain itu, menurut Wijaya dan Karneli (2017) diversifikasi produk pangan memberikan pengaruh positif dan signifikan terhadap kepuasan pelanggan.

Diversifikasi produk pangan berbasis air kelapa sangat mungkin dilakukan, karena air kelapa merupakan bagian dari buah kelapa yang kaya nutrisi, dan dapat diolah menjadi 
berbagai macam produk. Air kelapa mengandung kalori, glukosa, protein, lemak, karbohidrat, dan berbagai mineral seperti kalsium, kalium, magnesium, fosfor, potassium, sodium dan besi. Jumlah kandungan nutrisi ini berbeda antara air kelapa muda dengan air kelapa tua. Selain itu, perbedaan jenis kelapa juga memiliki perbedaan pada jumlah kandungan nutrisi, meskipun tidak terlalu signifikan (Palungkun, 1992; Barlina et al., 2007; Syafriani et al., 2014).

Air kelapa muda dapat diminum secara langsung sebagai minuman kesehatan. Air kelapa tua bisa diolah menjadi nata de coco, permen, kecap, sirup, minuman isotonik dan lain sebagianya. Pengolahan air kelapa menjadi berbagai macam produk ini dapat meningkatkan nilai tambah terhadap bahan baku air kelapa.

\section{Nata de Coco}

Pengolahan air kelapa menjadi nata de coco sudah banyak dilakukan. Berbagai penelitian tentang nata de coco menunjukkan bahwa nata de coco merupakan salah satu produk olahan berbasis air kelapa yang cukup prospektif. Nata de coco adalah produk olahan dari air kelapa yang difermentasi dengan bantuan asam asetat. Asam asetat tersebut diperoleh dari bakeri Acetobacter xylinum.

Secara umum, proses pengolahan nata de coco dimulai dengan penyaringan dan pemasakan air kelapa dengan penambahan asam cuka dan gula pasir. Setelah itu didinginkankan, untuk selanjutnya dilakukan inokulasi (penambahan inoculum Acetobacter xylinum). Selanjutnya dilakukan fermentasi selama 8 hari pada suhu 27$30^{\circ} \mathrm{C}$, dan terbentuklah nata de coco.

Pada proses fermentasi nata, diperlukan bakteri Acetobacter xylinum.
Nugroho dan Aji (2015) mencoba melakukan penelitian dengan menggunakan immobilisasi Acetobacter xylinum. Hasil yang diperoleh menunjukkan bahwa nata yang dihasilkan mencapai dua kali replikasi fermentasi, dengan waktu rata-rata fermentasi 11 hari, dan ketebalan nata rata-rata $0.8 \mathrm{~cm}$.

Putranto dan Taofik (2017) melakukan penelitian tentang penambahan ekstrak toge pada media nata de coco. Hasil yang diperoleh menunjukkan bahwa ekstrak toge 10\% menghasilkan nata de coco dengan karakteristik yang terbaik berdasarkan kadar air, kadar serat kasar, rendemen, ketebalan, warna, kekenyalan, dan rasa. Hal ini menunjukkan bahwa, penambahan bahan lain seperi toge dapat meningkatkan kualitas dan kuantitas dari nata de coco yang dihasilkan.

Selain penambahan sumber karbon (C), seperti fruktosa atau sukrosa, pertumbuhan bakteri Acetobacter xylinum juga memerlukan sumber nutrisi lain, seperti unsur nitrogen (N). Menurut Iguchi et al.(2000), unsur nitrogen yang dapat ditambahkan dalam pembuatan nata de coco adalah urea, ZA (ammonium sulfat), atau ekstrak yeast (khamir). Penelitian yang dilakukan Hamad dan Kristiono (2013) menunjukkan bahwa penambahan urea dalam pembuatan nata de coco menghasilkan yield dan ketebalan yang terbaik dibanding ZA dan yeast.

\section{Kecap Air Kelapa}

Kecap air kelapa adalah salah satu penyedap makanan atau bumbu dapur berbentuk cair dan berwarna hitam yang terbuat dari campuran air kelapa dengan penambahan rempah-rempah dan bumbu lainnya. Biasanya rempah yang ditambahkan adalah daun salam, pekak, sereh, dan lengkuas. Bumbu lain yang 
ditambahkan adalah gula merah, garam, natrium benzoate, dan $\mathrm{cmc}$, Pada umumnya kecap air kelapa memiliki rasa yang manis. Rasa manis diperoeh dari air kelapa itu sendiri dan juga penambahan gula merah.

Beberapa penelitian tentang kecap air kelapa sudah banyak dilakukan. Kandungan protein yang rendah pada air kelapa menyebabkan beberapa peneliti mencoba menambahkan bahan lain untuk meningkatkan kandungan protein kecap air kelapa yang dihasilkan. Silfia (2011) melakukan penelitian tentang kecap air kelapa dengan penambahan tepung tempe, dengan tujuan mengurangi keterganungan terhadap kacang kedele. Hasil yang diperoleh memperlihatkan bahwa kecap yang dihasilkan memiliki kandungan protein yang tinggi, yakni $6.24 \%$. Hasil ini diperoleh dari penambahan tepung tempe $10 \%$. Sejalan dengan itu, Kusumawardani (2011) juga melakukan penelitian tentang pemanfaatan air kelapa sebagai produk olahan kecap dengan penambahan bubuk kedelai dan bubuk tempe. Hasil yang diperoleh juga sudah sesuai dengan SNI kecap air kelapa.

Selanjutnya, Irtasari (2015) melakukan penelitian terkait usaha untuk meningkakan protein kecap dengan penambahan tepung belalang kayu dan sari buah nenas. Hasil yang diperoleh menunjukkan bahwa penambahan tepung belalang kayu 10 gram menghasilkan kandungan protein terlarut yang cukup tinggi, yakni 3.5\%. Kadar protein tersebut juga dipengaruhi oleh penambahan sari buah nenas.

Secara umum proses pengolahan kecap air kelapa adalah dengan mencampurkan air kelapa dengan gula merah, bumbu halus dan rempahrempah, kemudian memasaknya sambil diaduk. Setelah masak, kecap disaring dan setelah itu dimasak kembali dengan penambahan cmc, garam, natrium benzoate, dan penyedap rasa jika diperlukan.

\section{Sirup Air Kelapa}

Sirup air kelapa merupakan minuman berkadar gula tinggi yang terbuat dari air kelapa dengan penambahan bahan lainnya. Sirup ini memerluka proses pengenceran dalam penyajiannya, seperti halnya sirup pada umumnya. Penelitian terkait sirup air kelapa cukup banyak dilakukan. Hal ini menunjukkan bahwa sirup air kelapa cukup prospektif untuk dikembangkan, khususnya pada sentra-sentra kelapa seperti Kabupaten Indragiri Hilir-Riau, dan daerah lainnya yang kaya akan kelapa.

Yanti dan Asni (2014) melakukan penelitian tentang teknologi pengolahan sirup kelapa ramah lingkungan untuk pemberdayaan petani di lahan pasang surut provinsi Jambi. Hasil penelitian menunjukkan bahwa semua petani yang hadir menyatakan berminat dalam pembuatan sirup air kelapa yang cukup mudah dan dapat membantu ekonomi keluarga.

Sirup air kelapa pada umumnya menggunakan gula pasir sebagai tambahan pemanisnya. Marwanto et al.,(2016) melakukan penelitian tentang pengaruh konsentrasi gula kristal dan asam sitrat terhadap karekteristik fisik, kimia dan organoleptik sirup air kelapa. Hasil penelitian menunjukkan bahwa semakin banyak penambahan gula pasir maka kadar air sirup akan berkurang, begitu juga sebaliknya. Uji organoleptik menunjukkan konsentrasi gula $65 \%$ merupakan perlakuan terbaik.

Sirup air kelapa yang dibuat tanpa penambahan warna, akan terlihat kurang menarik. Oleh sebab itu, Hermente et al. (2017) melakukan kajian sifat fisik, 
kimia dan organoeptik sirup air kelapa dengan penambahan filtrate ubi jalar ungu. Hasil penelitian menunjukkan bahwa penambahan filtrat ubi jalar ungu mempengaruhi sifat organoeptik sirup air kelapa. Perlakuan yang terbaik adalah penambahan filtrat ubi jalar ungu sebanyak $20 \%$.

Secara umum proses pengolahan sirup air kelapa adalah dengan mencampur air kelapa tua dengan gula pasir, asam sitrat, cmc, dan pewarna yang disukai. Semua bahan dimasak hingga mendidih dan agak kental. Setelah dingin, sirup siap dikonsumsi.

\section{Produk Lain dari Air Kelapa}

Selain nata de coco, kecap, dan sirup, air kelapa dapat diolah menjadi permen,dan juga minuman isotonik. Studi pembuatan permen dari air kelapa yang dilakukan Jurait et al. (2016) menunjukkan bahwa analisa terbaik terdapat pada $20 \%$ air kelapa dan $80 \%$ air. Sedangkan penelitian tentang minuman isotonik dari air kelapa dilakukan oleh Langkong et al. (2018) dengan penambahan ekstrak belimbing wuluh. Hasil penelitian menunjukkan bahwa minuman isotonik yang dihasilkan memiliki aroma yang khas dengan kandungan nutrisi yang banyak. Nutrisi tersebut merupakan sumbangan dari air kelapa itu sendiri dan juga belimbing wuluh.

Selain itu, air kelapa juga bisa diolah menjadi cuka, cocojell, dan lain sebagainya. Kandungan nutrisi yang terdapat pada air kelapa menjadikan air kelapa bukan lagi sebagai limbah dari pengolahan minyak goreng, kopra, atau produk lainnya. Pengolahan dan diversifikasi produk yang dilakukan, akan meningkatkan nilai tambah air kelapa. Akibatnya harga penjualan pun meningkat, sehingga bisa mensejahterakan para petani kelapa khususnya pengrajin air kelapa.

\section{PENUTUP}

Air kelapa yang merupakan bagian dari buah kelapa dapat diolah lebih lanjut menjadi beraneka ragam produk olahan. Pengolahan dan diversifikasi produk olahan berbasis air kelapa bisa meningkatkan nilai tambah produk. Peningkatan nilai tambah bisa meningkatkan penghasilan pengrajin air kelapa secara finansial. Apalagi di daerah-daerah sentra kelapa, seperti Kabupaten Indragiri Hilir yang kaya akan kelapa.

Air kelapa bisa diolah menjadi nata de coco, kecap, dan sirup. Selain itu juga sebagai bahan baku permen, minuman isotonik, cuka, dan juga cocojell. Jika dikembangkan, konsumen akan bebas memilih produk yang mereka sukai, karena tersedia berbagai macam produk olahan dari air kelapa.

\section{DAFTAR PUSTAKA}

Barlina, R., Karouw, S., dan Hutapea, R. 2007. Pengaruh Perbandingan Air Kelapa dan Penambahan Daging Kelapa Muda serta Lama Penyimpanan terhadap Serbuk Minuman Kelapa. Jurnal Littri, Vol. 13, No. 12, Juni 2007. Pp: 7380.

Fitriani., Sarono., dan Widodo, Y.R. 2011. Tingkat Adopsi terhadap Diversifikasi Pangan Berbasis Jagung pada Organisasi Kelompok Masyarakat di Propinsi Lampung. Jurnal Agribisnis Politeknik Negeri Lampung Vol. 24, No. 1. Pp: 68-73.

Hamad, A. dan Kristiono. 2013. Pengaruh Penambahan Sumber Nitrogen terhadap Hasil Fermentasi Nata de Coco. Jurnal 
Momentum, Vol. 9, No. 1, April 2013. Pp: 62-65.

Hamente, D., Tamrin, dan Hermanto. 2017. Kajian Sifat Fisik, Kimia dan Organoleptik Sirup Air Kelapa dengan Penambahan Filtrat Ubi Jalar Ungu. Jurnal Sains dan Teknologi Pangan,JSTP) Vol. X, No. X. Pp: 664-676.

Hermawan, L. 2015. Strategi Diversifikasi Produk Pangan Olahan Tahu Khas Kota Kediri. Jurnal Jibeka Vol. 9, No. 2, Agustus 2015. Pp: 26-32.

Iguchi, M., Yamanaka, S. \& Budhiono, A. 2000. Bacterial Cellulose A Masterpiece Of Nature's Arts. Journal Of Material Science 35. Pp: $261-270$.

Irtasari. 2015. Kandungan Protein pada

Kecap Air Kelapa dengan Penambahan Tepung Belalang Kayu dan Sari Buah Nenas. [Skripsi] Fakultas Keguruan dan Ilmu Pendidikan Universitas Muhammadiyah Surakarta.

Jurait, M. dan Mardesci, H. 2016. Studi Pembuatan Permen dari Air Kelapa terhadap Karakteristik dan Penerimaan Konsumen. Jurnal Teknologi Pertanian, Fakultas Pertanian Universitas Islam Indragiri. Vol. 5, No. 1. Pp: 23-29.

Kusumawardani, W. 2011. Pemanfaatan Air Kelapa sebagai Produk Olahan Kecap dengan Penambahan Bubuk Kedelai dan Bubuk Tempe. [Skripsi] Fakultas Pertanian Universitas Sebelas Maret Surakarta.

Langkong, J., Sukendar, N.K., dan Ihsan, Z. 2018. Studi Pembuatan Minuman Isotonik Berbahan Baku Air Kelapa Tua (Cocos Nucifera L) dan Ekstrak Belimbing Wuluh (Avverhoa bilimbi L) Menggunakan Metode Sterilisasi
Non-Thermal Selama

Penyimpanan. Canrea Journal (Food Technology, Nuritition, and Culinary Journal). Vol.1, No.1. Pp: 53-62.

Marsigit, W. 2010. Pengembangan Diversisfikasi Produk Pangan Olahan Lokal Bengkulu untuk Menujang Ketahanan Pangan Berkelanjutan. Jurnal Agritech Vol. 30, No. 4, November 2010. Pp: 256-264.

Marwanto., Gusnawaty, dan Tamrin. 2016. Pengaruh Konsentrasi Gula Kristal dan Asam Sitrat terhadap Karakteristik Fisik, Kimia dan Organoleptik Sirup Air Kelapa. Jurnal Sains dan Teknologi Pangan,JSTP) Vol. 1, No. 3. Pp: 209-214.

Nugroho, D.A. dan Aji, P. 2015. Characterization of Nata de Coco Produced by Fermentation of Immobilized Acetobacter xylinum. Agriculture and Agricultural Science Procedia 3. Pp: $278-$ 282.

Palungkun, R. 1992. Aneka Produk Olahan Kelapa. Jakarta. Penerbit UI-Press.

Putranto, K. dan Taofik, A. 2017. Penambahan Ekstrak Toge pada Media Nata de Coco. ISTEK Jurnal Kajian Islam, Sains dan Teknologi. Fakultas Sains dan Teknologi Universitas Islam Negeri Sunan Gunung Djati Bandung. Edisi Juni 2017 Vol. X, No. 2. Pp: 138-149.

Silfia. 2011. Pengaruh Penambahan Tepung Tempe terhadap Mutu Kecap Air Kelapa. Jurnal Litbang Industri, Vol. 1, No.1. Pp: 22-29.

Syafriani, R., Sukandar, E.Y., Apriantono, T., dan Sigit, J.I. 2014. The Effect of Coconut Water (Cocos nucifera L.) and An 
Isotonic Drink on The Change of Heart Rate Frequency in The Rats Induced Hypertension. Procedia Chemistry 13. Pp: $177-180$.

Wijaya, Y.E. dan Karneli, O. 2017. Pengaruh Diversifikasi Produk dan Harga terhadap Kepuasan Pelanggan (Studi pada Pelanggan Kentucky Fried Chicken (KFC) Metropolitan City Pekanbaru.
Journal Online Mahasiswa Fakultas Ilmu Sosial dan Ilmu Politik Universitas Riau. Vol. 4., No. 2, Oktober 2017. Pp: 1-15.

Yanti, L., \& Asni, N. 2014. Teknologi Pengolahan Sirup Kelapa Ramah Lingkungan untuk Pemberdayaan Petani di Lahan Pasang Surut Provinsi Jambi. Konferensi Nasional Kelapa VIII. 